\title{
STAR AND POOR FUND PHENOMENA IN ISLAMIC- AND CONVENTIONAL-FOCUSED FAMILIES: EMERGING COUNTRY EVIDENCE
}

\author{
Anas Ahmad Bani Atta ${ }^{1}$ and Ainulashikin Marzuki ${ }^{2}$ \\ ${ }^{1}$ Universiti Sains Islam Malaysia (USIM), Malaysia, baniata_anas@hotmail.com \\ ${ }^{2}$ Universiti Sains Islam Malaysia (USIM), Malaysia, ainulashikin@usim.edu.my
}

\begin{abstract}
The aim of this study is to investigate star and poor phenomena and their impact on the flows of Islamic-focused family (IFF) and conventional-focused family (CFF). The sample includes the four emerging countries with the largest number of Islamic mutual funds from 2007 to 2018 (Saudi Arabia, Malaysia, Indonesia, and Pakistan). Panel regression analysis was used to examine the impact of dummy star and poor as independent variables, and family age, size, number of funds, past returns, and total risk as control variables for fund family flows. The results show that the dummy star has a significantly positive relationship with family flows. Family managers have succeeded in attracting more investors by using the strategy of advertising the best performing funds. However, in both, all families and IFF, the dummy poor has a negative relationship, but is insignificant. On the other hand, for CFFs, the dummy poor is significantly negative. This is because investors in IFFs, unlike those in CFFs, have more loyalty due to their moral and religious goals in addition to traditional goals. The novel finding of the study is the difference in the star phenomenon between the IFF and CFF. The findings are important for managers, as they will help them to create appropriate strategies to attract more flows and increase the assets under their management. In addition, the findings will help investors to direct their money to appropriate families.
\end{abstract}

Keywords: Islamic finance, Fund family, Star fund, Family flow.

JEL classification: G11; G12; G14; G23.

Article history:

Received : October 6, 2020

Revised : January 27, 2021

Accepted : March 8, 2021

Available online : May 20, 2021

https://doi.org/10.21098/jimf.v7i2.1349 


\section{INTRODUCTION}

\subsection{Background}

Islamic finance has grown significantly, at 10 to 12 percent yearly over the past decade (MIFC, 2020). As at July 2018, it was reported that the value of the Islamic finance industry was US\$2.2 trillion, and that it was expected to grow further to US\$3.8 trillion by 2022 (MIFC, 2020). This is in line with the forecast by the Pew Research Centre (2019) that the number of Muslims around the world was expected to increase steadily to 26.5 percent, 28.1 percent and 29.7 percent by 2030, 2040 and 2050, respectively, which will make the religion the second largest after Christianity.

Globally, the value of Islamic assets under management (AUM) was USD70.8 billion and the number of Islamic funds was 1,535 as of the first quarter of 2017, compared to USD\$47 billion and 802 funds in 2008 (MIFC, 2017). Out of the reported AUM value, equity funds (42 percent) were the largest type of fund, followed by money market funds (33.3 percent) and commodity funds (11.8 percent) (COMCEC, 2018). Saudi Arabia and Malaysia were the two countries with the largest AUM, at 35.6 percent and 31.9 percent respectively, out of global Islamic AUM as of the first quarter of 2017. In terms of the number of Islamic funds, the top four leading countries were Malaysia, Saudi Arabia, Indonesia, and Pakistan, with 371, 350, 155 and 83 funds respectively.

Overall, the size of the Islamic fund management industry is still small in comparison to that of the global fund management industry. For example, as of the end of 2016, the value of the former was only USD56.1 billion, compared to USD84.9 trillion for the global industry (COMCEC, 2018). It is therefore still regarded as a niche sector. However, Price Waterhouse Coopers (PWC) (2017) projects that the Islamic fund management industry will experience accelerating growth in the future, driven by the "personal wealth of mass affluent clients and high net worth individual (HNWI) followed by the wealth managed by pension funds and insurance companies" (COMCEC, 2018). HNWIs' wealth is forecast to nearly triple in size, surpassing USD100 trillion by 2025, driven by strong Asia Pacific growth (CWWR, 2016). In addition, the industry is now accessible to institutional investors as well as non-Muslim ones who regard Islamic funds as a subset of Socially Responsible Investment (SRI).

In conjunction with the growth of Islamic funds, investment families or asset management companies are growing in order to benefit from the opportunity of the increasing level of overall investor demand for new investment exposures in their portfolios. As at 2016, the top five largest asset management companies managing Islamic assets were concentrated in Saudi Arabia and Malaysia. These were NCB Capital (Saudi Arabia, AUM USD7, 445.9 million); Public Mutual (Malaysia, AUM USD 7,232 million); Jadwa Asset Management (Saudi Arabia, AUM USD 6,599.3 million); CIMB Islamic (Malaysia, AUM USD 4,890 million); and Samba Capital (Saudi Arabia, AUM USD 3,137 million). The three largest asset management companies in Pakistan, Al Meezan Investment Management, NBP Fullerton Asset Management and Alfalah GHP Investment, were ranked $21^{\text {st }}, 31^{\text {st }}$ and $35^{\text {th }}$, with AUM amounting to USD 914.1 million, USD 331.4 million and USD 178.9 million respectively. The top two asset management companies in Indonesia, Mandiri Investasi and Trimegah Asset Management, were ranked in $39^{\text {th }}$ and $46^{\text {th }}$ 
place out of the top asset management companies managing Islamic funds in the world, with AUM worth USD 123.5 million and USD 64.7 million respectively.

Despite the increased number of mutual fund families worldwide, Joo and Park (2011) indicate that some of these raise more capital from investors than others, concluding that this is because these families either have popular funds or that they are popular among investors. It is reasonable to assume that a fund or fund family is popular when investors think it will yield better returns, and that the best way to convince the general public that it will do this is to prove that certain funds in the family have done so in the past. Fund families demonstrate their superior performance by advertising their star performing funds to kindle investors' interest and investment in other family funds, making them inclined to take advantage of the spillover effect to maximise their overall inflow (Adrianto, Chen, \& How, 2019). The question is whether the existence of star or poor funds in the family contribute to the overall family flows. Most fund families are mixed, with the co-existence of both conventional mutual funds (CMFs) and Islamic mutual funds (IMFs). The attributes of IMFs differ from those of CMFs, so the assumption can be made that flows to families with a high focus on IMFs may differ from those to families highly focused on CMFs.

In spite of previous studies at the fund level, which propose that fund performance has a positive impact on fund cash flow (Marzuki \& Worthington, 2015; Azmi, Mohamad, \& Shah, 2018), no study has tested the rationality of fund investors who buy into another fund from the same star fund family. In addition, it is not known if star fund-owning families perform better than non-star ones. Therefore, this study is different from previous ones, in that it aims to analyse star fund-related phenomena at the fund family level, not the individual level. This perspective is very important, as many investors select funds based on the name and reputation of the fund family, instead of the fundamentals of the individual funds. This tendency is especially strong in emerging fund markets, where the lifetime and track records of individual funds are short, and therefore investors do not possess enough information about them. The motivation comes from whether managers can use their strategy to affect the behaviour of investors and then attract more flows. In addition, previous studies have focused only on developed countries and have not discussed families focused on Islamic funds. The studies of Nanda, Wang, and Zheng (2004) in the USA, and of Adrianto et al. (2019) in Korea, found that in the past stellar performance can attract more cash flow to the fund family to which it belongs. There is one piece of evidence regarding the SRI family in the USA, which obtained the same results (Joo \& Park, 2011).

\subsection{Objective}

The objective of this paper is to investigate the star phenomena of fund families in four countries: Malaysia, Saudi Arabia, Indonesia, and Pakistan. In addition, we also extend the investigation to establish whether star, or poor, phenomena contribute differently to the cash flow of families highly focused on IMFs, and to those more focused on CMFs. These four emerging countries were chosen as they are the top four Islamic countries in terms of Islamic assets under management, as well as having the highest number of Islamic funds in the world as of the first quarter of 2017 (MIFC, 2017). 
The remainder of this paper is organized as follows. Section 2 highlights the background of Islamic fund management, while Section 3 reviews the relevant literature. Section 4 presents the methodology used to achieve the objectives; Section 5 discusses and analyses the results; and Section 6 concludes the paper and offers some relevant recommendations.

\section{LITERATURE REVIEW}

\subsection{Islamic Fund Management Background}

Saudi Arabia and Malaysia are the two leading countries to capitalise on this emerging sector, and are recognised as leaders in Islamic finance development. They played a crucial role in building awareness, first of Islamic finance itself, and subsequently of Islamic asset management (Bani Atta \& Marzuki, 2019a). While these two nations have led the growth in the sector, other countries have quickly followed suit. The Islamic asset management industry has grown rapidly in many countries, including Ireland, the United States, Luxembourg, Indonesia, Kuwait, South Africa, Pakistan, and Jersey. In terms of the number of Islamic funds, the leading countries (excluding Malaysia and Saudi Arabia) are Indonesia, Pakistan, Luxembourg, Kuwait, Ireland, Mauritius, and the Cayman Islands (COMCEC, 2018).

Saudi Arabia has emerged as the largest financial market in the Islamic world, with many institutions and a sophisticated range of financial products. The impressive growth and performance of the equities market have led to the emergence of a large mutual fund industry (see Benjelloun \& Abdullah, 2009). As of late 2006, the size of the industry was estimated to be US\$37 billion, and included opportunities to invest in different categories such as stocks, bonds, and funds at the local, regional, and international levels. The mutual fund industry in Saudi Arabia started in 1992. Mutual funds were first introduced into the Malaysian financial system in 1959, when the first mutual fund management company was established, namely the Malaysian Unit Trust Limited (Abdul Rahman, Yahya \& Mohd Nasir, 2010). However, the company only launched its first mutual fund in 1966, after which it was renamed the Asia Unit Trust Berhad. The first Islamic mutual funds were launched in 1993 by the Arab Malaysian Unit Trust Berhad.

In Pakistan, the first open-end mutual fund was launched in 1962 (Khorana, Servaes \& Tufano, 2005), when the National Investment (Unit) Trust was set up. This was then followed closed-end mutual funds in 1966; both were stateowned. The first closed-end private sector mutual fund was launched in 1983. The Pakistan Mutual Funds Association (MUFAP) was first established in 1996, and the first Islamic mutual fund, the Al Meezan Mutual Fund, was launched on 13 July 1995 by Al Meezan Investment Management Limited. In 2003, Al Meezan was the first company allowed to operate as a full-fledged Shariah-compliant asset management company.

Indonesia is the world's most populous Muslim nation. The mutual fund industry here started in 1996 (Khorana et al., 2005), with only 25 funds and an AUM of USD 297.3 million, but the market has since grown rapidly. Islamic fund management in Indonesia is relatively young, with fund families having developed a relatively new range of Sharia-compliant mutual funds, with on average a 3 to 
4 years track record, and a relatively small asset size compared to Malaysia and Saudi Arabia, partly due to their focus on local investors. Indonesia's entry into Islamic asset management has been more recent compared to that of Malaysia, which explains its comparatively smaller asset sizes and shorter track record, as the focus has been more on local investors (GIFR, 2012).

\subsection{Background Theory}

Behavioural finance attempts to explain the behaviour of financial market players vis-à-vis the effects of psychological factors, and how these factors may lead to their decision-making in the market. It offers a scientific explanation which rebuts market efficiency. It attempts to do so by substituting conventional behaviour assumptions with models that integrate the systematic, observable human dimension. Bias among investors is caused primarily by their humanistic proclivity for overconfidence, and second by their desire to avoid regrets in the future (Barber \& Odean, 1999). Belsky and Gilovich (2010) defined behavioural finance as behavioural economics, and asserted that the field was born from the interweaving of economics and psychology, whose purpose is to investigate the underlying psychological reasons behind the financial decisions of an investor. In addition, Shefrin and Statman (2000) defined the science as "a rapidly growing area that deals with the influence of psychology on the behaviour of financial practitioners." Another definition of behavioural finance was proposed by Sewell (2007), as "the study of the influence of psychology on the behaviour of financial practitioners and the subsequent effect on markets."

The primary scope of this nascent field is the development of theories concerning the behaviour of investors, as well as their decision-making processes. Behavioural finance accommodates the possibility of psychological biases as the underlying reason for irregularities in the stock market, rather than considering them as mere chance, an argument purported by the market efficiency hypothesis (Fama, 1998). Information structure and the distinct characteristics of each market participant are expected to affect individual investors and market results (Banerjee, Kumar, Pande, \& Su, 2011). Behavioural finance has three main building blocks. The first is the limit to arbitrage, based on the premise that it is a difficult task for rational traders to undo displacements caused by less rational traders (Shiller, 2003). Therefore, potentially the irrational behaviour of market agents has a significant, long-term effect on market prices (Schindler, 2007). The second block is psychology. Behavioural finance refers to cognitive psychology evidence concerning biases that are related to an individuals' beliefs and preferences, and how their decisions are made on these. The final block is sociology; in which it is argued that social interaction influences investment decisions. This block disputes the traditional assumption that external factors do not affect financial decisions (Shiller, 2003). Major principles in behavioural finance, such as prospect theory (loss aversion, overconfidence, regret), have been established as contributing factors to irrational and sometimes harmful financial decision-making. 


\section{Prospect Theory}

Kahneman and Tversky (1979) argue that the prospect hypothesis proposes that people judge gains and losses differently and that they value gains more than losses, which is known as the impact of certainty. When people are given two equivalent choices, with a possible benefit option and a potential loss option, their decision will be based on the expected benefit rather than the loss, even though both options produce identical economic results. Kahneman and Tversky (1979) conducted a survey and demonstrated irrational behaviour. They found that most subjects chose the safe benefit alternative and at all costs avoided a certain loss. This suggests that people are risk-averse.

Prospect theory and utility theory are two models of decision-making processes that predict how people make decisions. Utility theory postulates that decisions depend on the usefulness of the decision-making result, while prospect theory proposes that decision-making outcomes under conditions of gains and losses are not symmetrical and that these are sometimes irrational decisions. The theory suggests that people assess the prospect of gains and losses rather than final assets, viewing gains and losses separately. The disposition effect (investors hold onto winning stocks too long and sell losing stocks too early) is explained in prospect theory in terms of loss aversion.

\section{a) Loss aversion}

Loss aversion is the tendency for people to prevent losses, rather than make gains. Previous studies suggest that losses are twice as powerful as gains in psychological terms (Kahneman \& Tversky, 1979). Losing one dollar is twice as traumatic as the pleasure of gaining one (Kahneman \& Tversky, 1991). Loss aversion happens when people are more prone to a decline in their wealth rather than an increase. This helps understand investors' propensity to sell winning stocks too quickly, while keeping loss-making ones.

\section{b) Regret theory}

Regret theory concerns people experiencing the pain of remorse for the mistakes they have made. Therefore, they change their behaviour and become irrational because of the fear of regret, which makes investors either risk-averse or riskseeking. Cognitive dissonance is a mental conflict that leads to a feeling of discomfort when people's belief is wrong; it is the creed of regret for mistakes. Subsequently, people change their attitudes, beliefs, and actions and act irrationally. According to Goetzmann and Peles (1997), investors who have made bad decisions and invested in losing stocks are unwilling to admit their mistake and therefore hold on to them. This leads to a positive convex relationship between past performance and flows.

\section{c) Overconfidence}

Overconfidence is behaviour in which people overestimate their knowledge and underreact to new information. This will lead investors to make mistakes because 
they do not know that they are at a knowledge disadvantage; they also tend to trade more frequently. In psychological research, Odean (1998) believed that an overconfident investor would underestimate risk. Barber and Odean (2001) subsequently found that men are more overconfident in financial decisions than women.

\section{d) Theoretical development}

The main aim of fund families is to maximise the assets under management. Family managers use their strategy to attract more investors and thus achieve this aim. According to previous studies, such as that of Nanda et al. (2004), who focused on conventional fund families in the USA); Joo and Park (2011), who examined conventional fund families in Korea); and Adrianto et al. (2019), who analysed SRI fund families in the USA), one of most important strategies used by managers is the advertising of the best performing funds in the family in an attempt to affect the behaviour of investors and attract them to the family. All these previous studies used dummy star or poor variables to establish whether managers were successful in using this strategy.

\subsection{Previous Studies}

From the 1990s, there has been a dramatic increase in the number of empirical studies of the relationship between mutual fund performance and the subsequent inflows of funds, which have also measured the behaviour of mutual fund investors. Past fund performance is one of the most important determinants of investors' money inflows, who tend to chase returns. In addition, studies have been made of investor responses to costs when investing in mutual funds. With regard to developed markets, there have been different studies on fund flows and performance, beginning with Smith (1978), and followed by the studies of Ippolito (1992), Hendricks, Patel, and Zeckhauser (1993), Roston and Sturges (1996), and Chevalier and Ellison (1997). Generally, it was found that the performance of funds and the money flow into them was positive and asymmetric. More recently, Chen and Qin (2016) examined the flow-performance relationship of US corporate bond funds over the period 1991 to 2014. They suggest that the flows of US corporate bond funds are responsive to fund performance, but that there is no evidence of sensitive convexity in the relationship between flow and performance. In relation to SRI funds, an analysis of 2,168 US equity funds from 2003 to 2011 by El Ghoul and Karoui (2017) found that they displayed a poorer flow-performance relationship compared to conventional funds. They also found some implications that ethical and traditional investor loyalties are more or less identical.

In terms of emerging markets, Leung and Kwong (2018) investigated the flowperformance relationship between mutual funds investing in emerging market economies (EMEs) from January 2000 to December 2016. Such funds demonstrated a convex relationship between flow and performance, thereby indicating that past performance was a significant factor driving fund inflow when the return on the fund was positive, but that its effect vanished when the return was negative. Marzuki and Worthington (2015) and Bani Atta and Marzuki (2019b) studied 
Islamic and conventional funds in the Malaysian market over the period 20012009. They found that Islamic fund investors were more receptive to poorly performing funds, thus suggesting that when selecting funds such investors were rational decision-makers. In addition, their analysis confirmed both Islamic and conventional funds' asymmetric and convex flow-performance relationships, as well as investors' best-performance-chasing behaviour. SRI funds have shown an asymmetric relationship between flow and performance; that is, investors' reaction to negative outcomes is not as aggressive as it is to positive returns (Azmi et al., 2018). Azmi et al. also observed a Sharia-compliant fund asymmetric flowperformance relationship during the period January 2002 to December 2013. Their investigation of global Islamic funds found evidence for such a relationship. Recently, Bani Atta and Marzuki (2020) found that the characteristics of fund families affected both Islamic and conventional funds within the family.

There is evidence which documents that fund flows in a fund family are affected by fund member performance, which is called the positive spillover effect (Weisbenner, 2008; Kempf \& Ruenzi, 2008; Nanda et al., 2004). This effect is useful for funds if the family owns one or more superior performance funds (star funds); these superior performers then help other funds in the same family to attract more flows. In contrast, losers do not experience large inflows of funds into the family, which are larger than the expected fund inflows for the fund's own performance. Khorana and Servaes (2012) noted that the existence of a star fund in a fund family will have a positive effect on the market shares of the family. They used a dummy variable called a star dummy, which was calculated by counting the number of funds in the fund family that fells within the top 5 percent of their objective class.

Various previous studies have also investigated funds' spillover effects by using different methodologies and different determinants in their fund flow models (Ippolito, 1992; Sirri \& Tufano, 1998; Weisbenner, 2008; Benson \& Faff, 2010; Joo \& Park, 2011; Adrianto et al., 2019). Some studies have investigated whether advertising and marketing have any spillover effect on new fund cash flows (Jain \& Wu, 2000; Barber, Odean \& Zheng, 2005; Gallaher, Kaniel \& Starks, 2006; Huang, Wei \& Yan, 2007). Nanda et al. (2004) found evidence of a spillover effect on cash flows to non-star performers in families with star funds. They defined star performing funds as ones in the top five percent of fund family adjusted returns. Studying a sample of 141,663 fund-year observations over the period 1992 - 1998, they found that flows to fund families with at least one-star fund were substantially higher than ones to families without a star fund. Furthermore, top-performing funds positively contributed to their own flows and to those of their sibling funds. However, there was no evidence of a similar spillover from lower ranking funds. Understanding the spillover effect in fund families is crucial in determining how to proportionally treat individual funds within a family. Khorana and Servaes (2012) found that the existence of a stellar fund performer provided a positive signal to investors about the reputation of a fund family. New flows were found to travel not only to the star fund itself but also to peer funds in the family. They reported that star funds positively affected the market share of a fund family, as demonstrated by an increase in the ratio of assets professionally managed by the family with a star performer to the total assets of the mutual fund industry. 
Later studies also investigated the benefits of having star performing funds in fund families. Most of these reported that having star performers "attracts higher cash flows to the family through a significant increase in inflows to the star performing funds, as well as through a spillover in the increased flows from those star performers to sibling funds. One such study was that of Joo and Park (2011), who investigated the contribution of star funds to fund families in the Korean fund market over the period 2001 to 2009. The results of their study showed that a star fund family that featured either star funds or higher relative holdings of star funds attracted more new investment than non-star fund families. The results also showed the existence of a spillover effect from star funds to non-star funds, which helped non-star funds and newly-launched ones in the family to raise fresh capital.

In the case of socially responsible investment (SRI) families, using a sample of USA SRI funds for the period 2000 to 2012, Adrianto et al. (2019) found that spillovers in cash flow to SRI funds within the fund family were due to the existence of a star (poor) performing peer SRI fund. The results of this study found a positive spillover effect from having a star SRI fund on the monthly cash flow of its SRI siblings. However, the reverse was not found in the presence of a poor SRI performer.

In summary, the studies which focus on the impact of star (poor) funds on the flows of fund families conclude that having at least one-star fund in the family help to increase the flows of conventional fund families (Nanda et al., 2004; Joo \& Park, 2011) and those of SRI fund families (Adrianto et al., 2019). All these three studies were based in developed countries (the USA and Korea). There no evidence concerning Islamic-focused families or emerging countries. To the best of our knowledge, ours is the first study to provide a comparison between the star phenomena which contribute to the flows of Islamic and conventional fund families in emerging countries, with the main focus on Islamic mutual funds.

\section{METHODOLOGY}

\subsection{Data}

The main source of mutual fund data was Bloomberg. The sample comprised 70 fund families, of which 25, 20, 14 and 11 were domiciled in Saudi Arabia, Malaysia, Indonesia, and Pakistan respectively, comprising a total of 502 funds. Following Tower and Zheng (2008), the sample of mutual fund families was restricted to those that held the majority of their assets in equities. The period covered was from 2007 until 2018, since most IMF data were available from 2007, and more than half of the sample were IMFs (344 funds). We excluded sector, international, global, balanced funds and bond funds, focusing only on family equity funds. We define an equity fund as one that invests at least $60 \%$ of its portfolio in equity. Furthermore, we divided the fund families into two categories: those with a high number of Islamic mutual funds and those with a high number of conventional mutual funds. For simplicity, in identifying families with a high number of Islamic mutual funds, we used a 33\% benchmark, following the screening methodologies adopted by most index provider companies, such as FTSE and MSCI. Based on the screening methodologies adopted by these indices, $33 \%$ is the maximum limit 
for having impermissible activities, which is based on the hadith that one third is the maximum limit. Therefore, in this study families with a high number of Islamic mutual funds are those with fewer than 33\% conventional equity funds, while families with more than $33 \%$ conventional equity funds are classified as high conventional mutual fund families. We term families with a high number of Islamic mutual funds as Islamic fund-focused families (IFFs), while those with a high number of conventional mutual funds are categorised as conventional fundfocused families (CFFs).

We calculated overall fund performance in the families using the Carhart fourfactor model. This has been widely used by previous studies as it includes returns and risk factors such as momentum. We then ranked the funds according their performance, using the ranking to identify the star and poor funds. Star funds are the top $5 \%$ ones, while poor funds are the bottom $5 \%$. Table 1 shows the number of star family poor family, star Islamic family, poor Islamic family, star conventional family, and poor conventional family funds. Previous studies, such as those of Nanda et al. (2004), Joo and Park (2011), and Adrianto et al. (2019) define star funds as the top five percent of funds based on the performance measurements over the preceding twelve months. They also describe a fund family with at least one-star fund as a 'star family' and one with at least one poor fund as a 'poor family'. The same top five percent rule was applied to define a star fund as in the previous literature, and the term 'poor fund' was also used to designate the opposite concept to a star fund, which is also defined as the bottom five percent of funds. We used a poor family to examine whether poor funds minimised the cash flow to a fund family, as well as investigating whether star funds raised the cash flow.

Table 1.

Summary of Star and Poor Islamic and Conventional Families

\begin{tabular}{lcccccc}
\hline Year & $\begin{array}{c}\text { Star Family } \\
\text { (Fund) }\end{array}$ & $\begin{array}{c}\text { Poor Family } \\
\text { (Fund) }\end{array}$ & $\begin{array}{c}\text { Star IFF } \\
\text { (Fund) }\end{array}$ & $\begin{array}{c}\text { Star CFF } \\
\text { (Fund) }\end{array}$ & $\begin{array}{c}\text { Poor IFF } \\
\text { (Fund) }\end{array}$ & $\begin{array}{c}\text { Poor CFF } \\
\text { (Fund) }\end{array}$ \\
\hline 2007 & $15(25)$ & $15(25)$ & $10(15)$ & $5(10)$ & $9(15)$ & $6(10)$ \\
2008 & $15(25)$ & $16(25)$ & $9(15)$ & $6(10)$ & $10(15)$ & $6(10)$ \\
2009 & $15(26)$ & $15(25)$ & $9(16)$ & $6(10)$ & $10(15)$ & $5(10)$ \\
2010 & $14(26)$ & $15(25)$ & $8(16)$ & $6(10)$ & $9(15)$ & $6(10)$ \\
2011 & $14(25)$ & $13(26)$ & $8(15)$ & $6(10)$ & $8(16)$ & $5(10)$ \\
2012 & $14(25)$ & $15(26)$ & $8(15)$ & $6(10)$ & $10(16)$ & $5(10)$ \\
2013 & $15(25)$ & $14(25)$ & $10(15)$ & $5(10)$ & $9(15)$ & $5(10)$ \\
2014 & $15(25)$ & $14(25)$ & $10(15)$ & $5(10)$ & $9(15)$ & $5(10)$ \\
2015 & $16(25)$ & $15(25)$ & $11(15)$ & $5(10)$ & $10(15)$ & $5(10)$ \\
2016 & $16(25)$ & $15(25)$ & $10(15)$ & $6(10)$ & $9(15)$ & $6(10)$ \\
2017 & $15(25)$ & $14(25)$ & $9(15)$ & $6(10)$ & $9(15)$ & $5(10)$ \\
2018 & $16(25)$ & $15(26)$ & $10(15)$ & $6(10)$ & $10(16)$ & $5(10)$ \\
\hline
\end{tabular}




\subsection{Model Development}

The model was applied to three samples: the all-family sample, family highly focused on IMFs, and family with a high focus on CMFs. Two explanatory variables were used, Dummy star and Dummy poor, in addition to a set of fund family attributes as control variables (past family returns, family age, family size, number of funds in the family, and total family risk).

Following previous studies (Nanda et al., 2004; Joo \& Park, 2011; Adrianto et al., 2019), this study employed a panel regression model to test the impact of the star and poor funds on the overall family flows. The use of a pooled or randomeffects model was determined by an LM test, and the use of a fixed-effects or random-effects model was determined by a Hausman test. The Chow test was then used to select the best model. The final results show that the appropriate model was the panel fixed-effects one.

$$
\begin{aligned}
\text { Newmoney }_{f, t} & =\alpha_{f}+\beta_{1} \operatorname{perf}_{f, t-1}+\beta_{2} N F_{f, t-1}+\beta_{3} F F A_{f, t-1}+\beta_{4} F F S_{f, t-1} \\
& +\beta_{5} T_{f, t-1}+\beta_{6} S F d u m m y_{f, t-1}+\beta_{7} \text { PFdummy }_{f, t-1}+\varepsilon_{f, t}
\end{aligned}
$$

where Newmoney f,t $_{t}$ is the money inflow of the fund family at time $t$; perf $f_{f, t-1}$ is the return of the family at time ${ }_{t-1} ; N F_{f, t-1}$ is the number of funds managed by the fund family; $F F A_{f, t-1}$ is the log number of years since the inception of the fund family; $F F S_{f, t-1}$ is the fund family size; and $T R_{f, t-1}$ is the total family risk. SFdummy $y_{f, t-1}$ is a dummy variable whose value is one if fund family $f$ has at least one fund that belongs to the top 5\% group based on the Carhart four-factor model; PFdummy $y_{f, t-1}$ is a dummy variable whose value is one if fund family $f$ has at least one fund that belongs to the bottom $5 \%$ group based on the Carhart four-factor; and $\varepsilon_{i, t}$ is the error term. If the regression coefficient of $S F d u m m y_{f, t-1}$ is positive, there is more cash inflow when fund family $f$ is a star fund family. Likewise, if the regression coefficient of PFdummy $y_{f, t-1}$ is negative, there is less cash inflow (or even cash outflow) when fund family $f$ is a poor fund family.

Following previous studies of mutual fund family performance (for example, Reinker \& Tower, 2004); Gallaher et al., 2006), we considered overall return as the measure of family performance. Specifically, we measured family return performance as the total net asset value weighted average of the performance of all equity funds in the family. The study period was between January 2007 and December 2018, focusing mainly on monthly returns. Relevant benchmarks were also collected from Bloomberg to compare the performance of the fund family under study to these. The FTSE All-World index is the most relevant benchmark for global funds since it covers the largest market capitalisation of global equity markets (Wilson \& Jones, 2002). The risk-free rate is the 3-month T-bill rate, which is used as a risk-free rate in many studies that have examined mutual fund performance.

$$
F R_{i, t}-R_{f, t}=\alpha_{i}+\beta_{i}\left(R_{m, t}-R_{f, t}\right)+\beta_{s} S M B_{t}+\beta_{v} H M L_{t}+\beta_{M} M O M_{t}+\varepsilon_{i, t}
$$


where $F R_{i, t}$ is the monthly return of a mutual fund family, measured by calculating the net asset value weighted portfolio of equity funds in the respective fund famil; $R_{f, t}$ is the risk-free rate, i.e., the US Treasury Bill; $R_{m, t}$ is the return of the market benchmark; $S M B_{t}$ is the return on the portfolio of small minus big stocks listed in the respective benchmark at time $t ; H M L_{t}$ is the return on the portfolio of high minus low book-to-market stocks listed in the respective benchmark at time $t ; M O M_{t}$ is the rate of return on the portfolio of high minus low momentum (previous 1-year return) stocks in the respective benchmark attime $t$.

We used new money growth as a dependent variable and calculated this following previous studies such as Nanda et al. (2004), Joo \& Park (2011) and Adrianto et al. (2019). The new money growth rate is defined as the net growth of total net assets that originate from new external money. To obtain this rate, the fund inflow into each fund first had to be calculated using Eq. (2); next, the total cash inflow for the family was computed using Eq. (3). Finally, Eq. (4) calculated the new money growth rate for the fund family in month $t$ :

$$
\begin{aligned}
& \text { Newmoney }_{i, t}=T N A_{i, t}-\operatorname{TNA}_{i, t-1} *\left(1+R_{i, t}\right) \\
& \text { Newmoney }_{f, t}=\sum_{i=1}^{n} \text { Newmoney }_{i, t} \\
& \text { NewmoneyGrowth }_{f, t}=\frac{\text { Newmoney }_{f, t}}{\sum_{i=1}^{n} \text { TNA }_{i, t-1}}
\end{aligned}
$$

where $T N A_{i, t}$ is the total net asset value of fund $\mathrm{i}$ in period $\mathrm{t}$; $T N A_{i, t-1}$ is the total net asset value of fund $\mathrm{i}$ in period $t-1$; and $R_{i, t}$ is the raw return of fund $\mathrm{i}$ in period $\mathrm{t}$.

\section{RESULTS AND ANALYSIS}

This section discusses the results of how the star and poor phenomena contributed to the overall fund family flows, as well as their contribution to the families mainly focused on IMFs and on CMFs. The fund family attributes are used as control variables.

\subsection{Preliminary Tests}

Table 2 shows the Breusch-Pagan/Cook-Weisberg test for heteroscedasticity. The results show $\mathrm{H} 0$ : constant variance, meaning that there is no heteroscedasticity, while prob>chi2 is 0.092 , higher than 0.05 , suggesting that the null hypothesis cannot be rejected. Given the potential problems of multicollinearity among the fund family attribute variables, a diagnostic check was performed using variance inflation factors (VIFs). As a rule of thumb, a VIF of $>10$ is taken to be an indicator of the presence of multicollinearity; the diagnostic results in Table 2 show that none of the family characteristic variables have a value greater than 10 , suggesting that there is no multicollinearity. 
Table 2.

Breusch-Pagan/Cook-Weisberg and VIF Test

\begin{tabular}{lccc}
\hline Variable & VIF & 1/ VIF & Heteroscedasticity test \\
\hline Family Age & 1.40 & 0.7134 & \\
Number of Funds & 1.30 & 0.7717 & \\
Family Size & 1.14 & 0.8770 & \\
Past Flows & 1.13 & 0.8866 & H0: Constant variance \\
Star Dummy & ---- & ---- & Prob $>$ Chi2 $=0.092$ \\
Poor Dummy & ---- & --- & \\
Past Performance & 1.04 & 0.9593 & \\
Total Risk & 1.07 & 0.8954 & \\
Mean VIF & 1.18 & ----- & \\
\hline
\end{tabular}

\subsection{Descriptive Statistics}

Table 3 shows the descriptive statistics of the variables used in the analysis, namely the explanatory and control variables. There are 70 families, 41 of which are highly focused on IMFs, as all families in Saudi Arabia are focused on these, in addition to the study sample included the four Islamic country. This also notes on the number of IMFs (304) compared with that of CMFs (198). The mean of new money growth is positive and equal to 0.3187 , and the standard deviation is equal to 0.0829 , which means that the fund families received an overall positive net inflow during the sample period. Both IMF-focused and CMF-focused families show positive new money growth, with totals of 0.216 and 0.066 respectively. This indicates that both types of fund family received an overall positive net inflow during the sample period. However, the IMF-focused ones received more net money flow than the CMF-focused, because Malaysia and Saudi Arabia led the sample data, and both countries have a large number of IMFs. The number of star funds is $25(5 \%$ *502), with $15(5 \% * 304)$ in the Islamic- focused family and 10 $\left(5 \%{ }^{*} 198\right)$ in the conventional one. Similarly, the number of poor funds is $25 ; 15$ in the Islamic-focused family, and 10 in the conventional one. The average returns for the three samples are negative, for all family sample the current returns -0.073 as well as the past -0.005 . For the IMF-focused family sample, the current returns are -0.003 and the past ones -0.032 . For the CMF- focused family sample, the current returns are -0.147 and the past ones -0.107 . The IMF-focused family shows higher current month returns and past one month returns. This implies that, collectively, for all the family samples, despite the presence of negative returns for both types of focus, the IMF-focused family average return performance is better than that of the CMF equivalent. 
Table 3.

Descriptive Statistics

\begin{tabular}{lccccccccccccc}
\hline Sample & \multicolumn{3}{c}{ All family } & \multicolumn{4}{c}{$\begin{array}{c}\text { IMF-focused } \\
\text { family }\end{array}$} & \multicolumn{3}{c}{$\begin{array}{c}\text { CMF-focused } \\
\text { family }\end{array}$} & \multicolumn{2}{c}{$\begin{array}{c}\text { Equality of } \\
\text { variance }\end{array}$} & \multicolumn{2}{c}{$\begin{array}{c}\text { Equality of } \\
\text { means }\end{array}$} \\
\hline Variable & $\mathbf{N}$ & Mean & S.D & N & Mean & S.D & N & Mean & S.D & t-stat & p-value & t-stat & p-value \\
\hline N. Fund & 502 & 497.3 & 7.819 & 304 & 311.4 & 9.168 & 198 & 131.2 & 8.147 & 7.868 & 0.000 & 9.970 & 0.000 \\
N. fam & 70 & 66.8 & 5.742 & 41 & 40.6 & 4.481 & 29 & 27.2 & 3.955 & 5.215 & 0.000 & 8.577 & 0.000 \\
N. star. F & 25 & 24.67 & 1.781 & 15 & 14.20 & 3.432 & 10 & 8.5 & 2.139 & 3.163 & 0.051 & 3.021 & 0.001 \\
N. poor. F & 25 & 24.42 & 1.622 & 15 & 14.65 & 2.658 & 10 & 8.4 & 2.617 & 3.256 & 0.065 & 2.932 & 0.005 \\
N.M.G & 840 & 0.3187 & 0.082 & 492 & 0.216 & 0.053 & 348 & 0.066 & 0.315 & 9.028 & 0.000 & 8.597 & 0.000 \\
Fam Ret & 840 & -0.073 & 1.235 & 492 & -0.003 & 0.184 & 348 & -0.147 & 0.057 & 1.096 & 0.000 & 2.340 & 0.000 \\
Fam age & 840 & 17.74 & 1.421 & 492 & 17.73 & 1.421 & 348 & 17.76 & 2.455 & -2.262 & 0.012 & -1.974 & 0.000 \\
Fund/fam & 840 & 7.183 & 2.453 & 492 & 7.164 & 2.296 & 348 & 7.200 & 2.721 & -3.585 & 0.000 & -3.123 & 0.000 \\
Fam size & 840 & 1850.6 & 430.5 & 492 & 1522.5 & 446.2 & 348 & 1270 & 419.5 & 32.42 & 0.000 & 43.83 & 0.000 \\
P. return & 840 & -0.032 & 0.051 & 492 & -0.005 & 0.184 & 348 & -0.107 & 0.058 & 3.051 & 0.000 & 2.697 & 0.000 \\
\hline
\end{tabular}

Table 3 also shows that the average age of the fund families in all the samples was 18 years. Their average size for all countries in terms of number of funds is seven funds, while by the average total net asset value is USD 1,850.6 million. The average age of the IMF-focused family (17.73 years) is slightly less than the CMFfocused one (17.76 years), which might explain why the number of funds in the former (7.1 funds) is slightly lower than that in the latter (7.2 funds). Despite being younger and having a smaller number of funds in the family, the IMF-focused family size by total net asset value of USD 1522.5 million is larger than that of the CMF family size of USD 1270 million.

\subsection{Correlation}

Table 4 presents the pairwise correlations for fund family new money growth and the independent variables. In addition, below the correlation coefficients the $\mathrm{p}$-values for the tests of significance of the coefficients are given. To check if the problem of multicollinearity exists. Fund family new money growth is correlated positively with fund family age, the number of funds in the family, past family returns, and the star dummy. This means that the older fund families attract more money flows than the younger ones. In addition, according to the number of funds in the family, the larger ones attract more money flows than the smallest. Finally, fund families with star funds attract more money flows. However, fund family new money is correlated negatively with family size, total risk, and poor dummy. This suggests that according to the TNA large fund families attract less money flows than the smaller ones, and that fund families with more total risk attract less money flows than those with less total risk. In addition, fund families with poor funds have more money outflows. Finally, the correlation between the other fund family attributes is relatively low and unlikely to lead to a multicollinearity problem. 
Table 4.

Correlation Matrix

\begin{tabular}{|c|c|c|c|c|c|c|c|c|}
\hline Variable & N.M.G & $\begin{array}{l}\text { Family } \\
\text { Age }\end{array}$ & $\begin{array}{l}\text { No. of } \\
\text { Funds }\end{array}$ & $\begin{array}{c}\text { Family } \\
\text { Size }\end{array}$ & D Star & D Poor & $\begin{array}{c}\text { Past } \\
\text { Return }\end{array}$ & $\begin{array}{l}\text { Total } \\
\text { Risk } \\
\end{array}$ \\
\hline N.M.G & 1.000 & --- & --- & --- & --- & --- & --- & --- \\
\hline Family Age & $\begin{array}{c}0.199 \\
(0.000)\end{array}$ & 1.000 & --- & --- & --- & --- & --- & --- \\
\hline $\begin{array}{l}\text { Number of } \\
\text { Funds }\end{array}$ & $\begin{array}{c}0.217 \\
(0.000)\end{array}$ & $\begin{array}{c}0.187 \\
(0.000)\end{array}$ & 1.000 & --- & --- & --- & --- & --- \\
\hline Family Size & $\begin{array}{l}-0.080 \\
(0.041)\end{array}$ & $\begin{array}{l}-0.203 \\
(0.000)\end{array}$ & $\begin{array}{c}0.345 \\
(0.000)\end{array}$ & 1.000 & --- & --- & --- & --- \\
\hline D Star & $\begin{array}{c}0.714 \\
(0.000)\end{array}$ & $\begin{array}{c}0.060 \\
(0.082)\end{array}$ & $\begin{array}{c}0.190 \\
(0.000)\end{array}$ & $\begin{array}{l}-0.056 \\
(0.107)\end{array}$ & 1.000 & --- & --- & --- \\
\hline D Poor & $\begin{array}{l}-0.043 \\
(0.204)\end{array}$ & $\begin{array}{c}0.075 \\
(0.030)\end{array}$ & $\begin{array}{c}0.192 \\
(0.000)\end{array}$ & $\begin{array}{l}-0.038 \\
(0.273)\end{array}$ & $\begin{array}{l}-0.010 \\
(0.782)\end{array}$ & 1.000 & --- & --- \\
\hline $\begin{array}{l}\text { Past } \\
\text { Returns }\end{array}$ & $\begin{array}{c}0.152 \\
(0.000)\end{array}$ & $\begin{array}{l}-0.124 \\
(0.003)\end{array}$ & $\begin{array}{l}-0.141 \\
(0.000)\end{array}$ & $\begin{array}{c}0.073 \\
(0.034)\end{array}$ & $\begin{array}{c}0.029 \\
(0.000)\end{array}$ & $\begin{array}{l}-0.150 \\
(0.000)\end{array}$ & 1.000 & --- \\
\hline Total Risk & $\begin{array}{l}-0.032 \\
(0.237)\end{array}$ & $\begin{array}{l}-0.117 \\
(0.006)\end{array}$ & $\begin{array}{l}-0.150 \\
(0.000)\end{array}$ & $\begin{array}{l}-0.019 \\
(0.569)\end{array}$ & $\begin{array}{l}-0.003 \\
(0.914)\end{array}$ & $\begin{array}{c}0.011 \\
(0.744)\end{array}$ & $\begin{array}{l}-0.227 \\
(0.000)\end{array}$ & 1.000 \\
\hline
\end{tabular}

\subsection{Empirical Regression Results}

Table 5 shows the estimated coefficients of the impact of star and poor funds on fund family new money growth for all fund families, the IMF-focused family, and the CMF-focused family.

\section{a. Overall fund families}

In this section, we examine whether having at least one-star fund in the family attracts investment capital into the family as a whole, and whether the presence of a poor fund will lead to withdrawals of capital. 'New money growth to the fund family' is the dependent variable and 'the star and poor fund family dummies' are the principal explanatory variables. The coefficients of the variable of past family returns are positive and overall statistically significant; this supports the conclusion that fund family performance and money flow into the family are positively related. There is a highly significant positive relationship between the current fund family flow growth and the lag fund family return. The majority of previous researchers have found a strong positive relationship between flows and the performance variable at both fund and family level (Chevalier \& Ellison, 1997; Sirri \& Tufano, 1998; Del Guercio \& Tkac, 2002; Berk \& Green, 2004; Nanda et al., 2004; Adrianto et al., 2019).

As the growth of fund family flow is positively linked to the strategy of generating a star resulting from the high standard deviation, we conclude that investment in the fund family, calculated by the growth of the fund flow, implies that high-risk investment will yield high returns. It is important to note that the coefficient of the main explanatory variable dummy star has a positive and statistically significant relationship with the dependent variable, indicating that a star family can increase money flows. In contrast with the dummy star family, the 
coefficients of the dummy poor one were negative, but not statistically significant, thereby implying there were no significant money outflows due to poor funds in the family. This result can be understood with reference to the previous studies of Goetzmann and Pales (1977) and Sirri and Tufano (1998), who found that poor performance in funds was not related to money outflow at the individual fund level due to cognitive-dissonance bias. In addition, Nanda et al. (2004) and Joo and Park (2011) also recorded the same results at the family level.

The results show that the star fund families received more money inflows when using star fund ownership to define themselves. The coefficient of the dummy star is 0.940 , which indicates that there is a strong positive relationship between the possession of star funds and new money growth in fund families. When the fund family has one-star fund, new money growth increases by 0.940 units. The coefficient of the dummy poor family shows a negative and insignificant relationship of -0.172 . There is no indication that investors withdraw funds from poor families; having a poor fund would not, therefore, result in money flowing out of the families. The fund families have enough funds and are in a position to undertake the strategy of creating stars, since according to Guedj and Papastaikoudi (2005), the number of funds in a family needs to be sufficiently high to selectively promote its funds. In addition, investors in fund families are sophisticated, and are not in a hurry to realise their winning funds (Grinblatt \& Keloharju, 2000; Nanda et al., 2004). Hence, investors might not be influenced by the disposition effect, by which unsophisticated investors dispose of funds that make a profit and sit on losing funds (Shefrin \& Statman, 1985; Grinblatt \& Kelohar, 2001; Weber \& Camerer, 1998; Odean, 1998). Moreover, the significant positive relationship between star funds and family flows shows that families which include such funds benefit more widely across their other funds. Given their reputation, star funds may reduce marketing costs and signal the good timing and selectivity of the family's management team, whereas poor funds may work in the opposite direction.

Table 5.

Regression Estimates

\begin{tabular}{lccc}
\hline Variable & Fund family & IMF-focused family & CMF-focused family \\
\hline \multirow{2}{*}{ Constant } & -0.466 & -0.684 & -0.525 \\
& $(0.068)$ & $(0.360)$ & $(0.206)$ \\
Family Age & 0.014 & 0.027 & -0.021 \\
& $(0.000)^{*}$ & $(0.002)^{* *}$ & $(0.532)$ \\
Number of Funds & 0.012 & 0.003 & -0.014 \\
& $(0.027)^{*}$ & $(0.046)^{*}$ & $(0.620)$ \\
Family Size & 0.386 & 0.034 & 0.433 \\
& $(0.422)$ & $(0.979)$ & $(0.028)^{*}$ \\
Dummy Star & 0.940 & 0.981 & 0.324 \\
& $(0.000)^{* *}$ & $(0.000)^{* *}$ & $(0.000)^{* *}$ \\
Dummy Poor & -0.172 & -0.280 & -0.078 \\
& $(0.521)$ & $(0.209)$ & $(0.044)^{*}$ \\
Past Family Returns & 0.149 & 0.242 & 0.107 \\
& $(0.042)^{* *}$ & $(0.025)^{* *}$ & $(0.046)^{* *}$ \\
\hline
\end{tabular}


Table 5.

Regression Estimates (Continued)

\begin{tabular}{lccc}
\hline Variable & Fund family & IMF-focused family & CMF-focused family \\
\hline Total risk & -0.018 & -0.189 & -0.469 \\
& $(0.010)^{*}$ & $(0.049)^{*}$ & $(0.241)$ \\
LM Test & 278.81 & 120.72 & 261.61 \\
& $(0.001)^{* *}$ & $(0.006)^{* *}$ & $(0.003)^{* *}$ \\
Hausman Test & 338.50 & 319.01 & 401.22 \\
Prob $>$ F & $(0.003)^{* *}$ & $(0.004)^{* *}$ & $(0.005)^{* *}$ \\
Adjusted. $R^{2}$ & 0.0000 & 0.0000 & 0.0000 \\
\hline
\end{tabular}

Note: ${ }^{*} \%$ significance level, $* * 5 \%$ significance level and ${ }^{* * *} 10 \%$ significance level.

\section{b. IMF-focused family vs CMF-focused family}

This subsection compares the effect of star and poor funds on IMF-focused and CMF-focused family new money growth. The coefficient of the main explanatory variable dummy star has a positive and statistically significant relationship with the dependent variable in both fund family types, at 0.981 and 0.324 respectively. This indicates that star funds can increase the money flows of both types of family, meaning the management teams of the both fund family types have been successful in using the strategy of advertising star funds to attract more flows.

At the same time, the dummy poor fund has a negative relationship with IMFfocused family new money growth, but is insignificant; investors in this type of family do not withdraw funds out of poor fund families. This result is similar to those of the all-family sample. While the results of the CMF-focused family are different, the dummy poor fund has a negative relationship with its new money growth and is significant, so investors in the CMF-focused family withdraw funds out of poor fund families. These results are in line with Adrianto et al., (2019), who indicated that the influence of star funds varies between SRI families and conventional ones. The results can be justified by the fact that investors in this fund family type are unsophisticated, seeking to unload such funds as soon as possible. In addition, unlike investors in the IMF-focused family, they do not have any religious goals, thus also leading them to dispose of poor funds. Moreover, this could be justified by the fact that the IMF-focused family has more restrictions than the CMF-focused one. IMFs are focused on religion and ethical goals in addition to traditional ones, which may reduce the freedom of movement between families, and thus force investors to retain their money due to the lack of options available to them.

\section{CONCLUSION AND RECOMMENDATIONS}

\subsection{Conclusion}

The objective of this study was to investigate star and poor phenomena and their impact on the flows of fund families, as well as to examine whether there is a difference in this phenomenon between families focused on Islamic mutual funds (IMFs), and those focused on conventional mutual funds (CMFs). The sample 
included four emerging countries with the highest number of IMFs (Saudi Arabia, Malaysia, Indonesia, and Pakistan) from 2007 to 2018. Panel regression analysis (a fixed-effects model) was used to examine the impact of the two main explanatory variables (dummy star and poor) and a set of family attributes as control variables (age, size, number of funds, past returns, and total family risk). The results indicate that star funds attract more flows to their family, with the relationship being significantly positive with the family NMG. This means that family managers have succeeded in using a successful fund announcement strategy to attract more investors and thus increasing family flows. For the all- family sample and Islamicfocused families, the dummy poor does not lead to cash outflows in the fund family flows. However, in the conventional-focused family sample, the dummy poor has a significantly negative relationship with the family NMG. This indicates that the existence of poor funds leads to cash outflows from the family. The novel finding made by the study relates to the difference in the star phenomenon between Islamic and conventional fund- focused families. The findings are important for managers and they will help them to create appropriate strategies to attract more flows and thus increase the assets under their management. In addition, the results are important for investors as they will help them to direct their money to appropriate families. The study is also important because it provides participants with an overview of IMF and CMF flows concurrently. Moreover, to the best of our knowledge, the data used in this study are more recent and comprehensive than those employed in previous studies.

\subsection{Recommendations}

The results obtained provide crucial information for practitioners in the mutual fund industry; for example, they will help family managers to design appropriate strategies. According to the results, family managers are able to expect the appropriate funds to the family, where the Islamic investors direct their money to the families with star funds, while they do not punish poor-performing funds in the family.

The findings will also help investors choose better families from which to select funds. As most investors follow a top-down approach, they choose fund families first and then select individual funds from them. According to the results, the presence of star funds in families is an indication of the skill of the management team and thus helps achieve better performance, which facilitates the decisionmaking process for investors.

It can be concluded that IMFs can play an important role in social finance and also be extended to non-Muslim countries, so academics and researchers are recommended to focus on Islamic investment and extend their studies to other countries, both developed and emerging ones. Finally, the study recommends that regulators and practitioners focus more on IMFs and Islamic investment when making decisions. 


\section{REFERENCES}

Abdul Rahman, A., Yahya, M. A., \& Mohd Nasir, M. H. (2010). Islamic norms for stock screening: A comparison between the Kuala Lumpur stock exchange Islamic index and the Dow Jones Islamic market index. International Journal of Islamic and Middle Eastern Finance and Management, 3(3), 228-240.

Adrianto, F., Chen, E., \& How, J. C. Y (2019). Spillover effects in SRI fund families. Available at SSRN: https://ssrn.com/abstract=3311876. or http://dx.doi. org/10.2139/ssrn.3311876.

Azmi, W., Mohamad, S., \& Shah, M. E. (2018). Nonfinancial traits and financial smartness: International evidence from Shariah-compliant and Socially Responsible funds. Journal of International Financial Markets, Institutions and Money, 56(September 2018), 201-217.

Banerjee, A. V, Kumar, S., Pande, R., \& Su, F. (2011). Do informed voters make better choices? Experimental evidence from urban India. Unpublished Manuscript. Retrieved from http://www.hks.harvard.edu/fs/rpande/papers/ DoInformedVoters_Nov11.pdf.

Bani Atta, A., \& Marzuki, A. (2019a). The determinants of Islamic mutual fund flows: Evidence from Malaysia. International Journal of Advanced Research in Economics and Finance, 1(1), 10-21.

Bani Atta, A., \& Marzuki, A. (2019b). The impact of funds and fund family characteristics on fund performance: Evidence from Malaysia. Journal of Wealth Management E Financial Planning, 6(June 2019), 3-23.

Bani Atta, A., \& Marzuki, A. (2020). Islamic vs conventional funds within the family: Selectivity skills and market timing ability. Journal of Islamic Monetary Economics and Finance, 6(2), 439-462.

Barber, B. M., \& Odean, T. (1999). The courage of misguided convictions. Financial Analysts Journal, 55(6), 41-55.

Barber, B. M., \& Odean, T. (2001). Boys will be boys: Gender, overconfidence, and common stock investment. Quarterly Journal of Economics, 116(1), 261-292.

Barber, B. M., Odean, T., \& Zheng, L. (2005). Out of sight, out of mind: The effects of expenses on mutual fund flows. Journal of Business, 78(6), 2095-2119.

Belsky, G., \& Gilovich, T. (2010). Why smart people make big money mistakes and how to correct them: Lessons from the life-changing science of behavioral economics. New York: Simon and Schuster Paperbacks.

Benjelloun, H., \& Abdullah, A. M. A. (2009). Index funds and diversification in Saudi Arabia. International Journal of Islamic and Middle Eastern Finance and Management, 2(3), 201-212.

Benson, K. L., \& Faff, R. W. (2010). The simultaneous relation between fund flows and returns. Australian Journal of Management, 35(1), 51-68.

Berk, J. B., \& Green, R. C. (2004). Mutual fund flows and performance in rational markets. Journal of Political Economy, 112(6), 1269-1295.

Chen, Y., \& Qin, N. (2016). The behavior of investor flows in corporate bond mutual funds. Management Science, 63(5), 1365-1381.

Chevalier, J., \& Ellison, G. (1997). Risk taking by mutual funds as a response to incentives. Journal of Political Economy, 105(6), 1167-1200.

COMCEC (2018). Islamic fund management. Standing committee for economic and commercial cooperation of the organization of Islamic cooperation (COMCEC), 
COMCEC Coordination Office, October 2018. Retrieved from http://www. comcec.org/en/wp-content/uploads/2018/11/11-FIN-AN.pdf.

Del Guercio, D., \& Tkac, P. A. (2002). The determinants of the flows of funds of managed portfolios: Mutual funds vs pension funds. Journal of Financial and Quantitative Analysis, 37(4), 523-557.

El Ghoul, S., \& Karoui, A. (2017). Does corporate social responsibility affect mutual fund performance and flows? Journal of Banking and Finance, 77(April 2017), 53-63.

Fama, E. F. (1998). Market efficiency, long-term returns, and behavioral finance. Journal of Financial Economics, 49(3), 283-306.

Gallaher, S., Kaniel, R., \& Starks, L. T. (2006). Madison Avenue meets wall street: Mutual fund families, competition and advertising SSRN (January 2006), 1-46. http://dx.doi.org/10.2139/ssrn.879775.

Goetzmann, W. N., \& Peles, N. (1997). Cognitive dissonance and mutual fund investors. Journal of Financial Research, 20(2), 145-158.

Grinblatt, M., \& Keloharju, M. (2000). The investment behavior and performance of various investor types: A study of Finland's unique data set. Journal of Financial Economics, 55(2000), 43-67.

Grinblatt, M., \& Keloharju, M. (2001). How distance, language, and culture influence stockholdings and trades. The Journal of Finance, 56(3), 1053-1073.

Hendricks, D., Patel, J., \& Zeckhauser, R. (1993). Hot hands in mutual funds: Shortrun persistence of relative, 1974- 1988. The Journal of Finance, 48(1), 93-130.

Huang, J., Wei, K. D., \& Yan, H. (2007). American finance association participation costs and the sensitivity of fund flows to past performance. The Journal of Finance, 62(3), 1273-1311.

Ippolito, R. A. (1992). Consumer reaction to measures of poor quality: Evidence from the mutual fund industry. The Journal of Law and Economics, 35(1), 45-70.

Jain, P. C., \& Wu, J. S. (2000). Truth in mutual fund advertising: Evidence on future performance and fund flows. The Journal of Finance, 55(2), 937-958.

Joo, H. K., \& Park, Y. K. (2011). Contribution of star funds to fund families: An empirical analysis of the Korean fund market. Asia-Pacific Journal of Financial Studies, 40(5), 731-762.

Kahneman, D., \& Tversky, A. (1979). Prospect theory: An analysis of decision under risk. Econometric, Journal of the Econometric Society, 47(2), 263-291.

Kempf, A., \& Ruenzi, S. (2008). Family matters: Rankings within fund families and fund inflows. Journal of Business Finance and Accounting, 35(1-2), 177-199.

Khorana, A., \& Servaes, H. (2012). What drives market share in the mutual fund industry? Review of Finance, 16(1), 81-113.

Khorana, A., Servaes, H., \& Tufano, P. (2005). Explaining the size of the mutual fund industry around the world. Journal of Financial Economics, 78(1), 145-185.

Leung, D., \& Kwong, M. (2018). The flow-performance relationship in emerging market bond funds. HKIMR Working Paper, 4/2018, 1-44.

Malaysia International Islamic Finance Centre (MIFC). (2020). Islamic funds in Southeast Asia. Retrieved from http://www.mifc.com/index.php?ch_contents_ capital_markets\&pg_cm_global\&ac=27915. 
Malaysia. World's Islamic Finance Marketplace (MIFC). (2017). Islamic funds: Gearing up. Retrieved from http://www.mifc.com/index. php?ch=28\&pg=72\&ac $=180 \& b b=$ uploadpdf.

Marzuki, A., \& Worthington, A. (2015). Comparative performance-related fund flows for Malaysian Islamic and conventional equity funds. International Journal of Islamic and Middle Eastern Finance and Management, 8(3), 380-394.

Nanda, V., Wang, Z. J., \& Zheng, L. (2004). Family values and the star phenomenon: Strategies of mutual fund families. The Review of Financial Studies, 17(3), 667698.

Odean, T. (1998). Are investors reluctant to realize their losses? The Journal of Finance, 40(5), 52-58.

Reinker, K. S., \& Tower, E. (2004). Index fundamentalism revisited. Journal of Portfolio Management, 30(4), 1-35.

Roston, G. P., \& Sturges, R. H. (1996). Using the genetic design methodology for structure configuration. Computer-Aided Civil and Infrastructure Engineering, 11(3), 175-183.

Schindler, M. (2007). Rumors in financial markets: Insights into behavioral finance (Vol. 413). Chichester: John Wiley \& Sons.

Sewell, M. (2007). Behavioural finance. February 2007.University of Cambridge, $1-14)$.

Shefrin, H., \& Statman, M. (2000). Behavioral portfolio theory. Journal of Financial and Quantitative Analysis, 35(2), 127-151.

Shiller, R. J. (2003). From efficient markets theory to behavioral finance. The Journal of Economic Perspectives, 17(1), 83-104.

Sirri, E. R., \& Tufano, P. (1998). Costly search and mutual fund flows. The Journal of Finance, 53(5), 1589-1622.

Smith, M. B. (1978). Psychology and values. Journal of Social Issues, 34(4), 181-199.

Tower, E., \& Zheng, W. (2008). Ranking mutual fund families: Minimum expenses and maximum loads as markers for moral turpitude. International Review of Economics, 4(55), 315-322.

Weber, M., \& Camerer, C. F. (1998). The disposition effect in securities trading: An experimental analysis. Journal of Economic Behavior and Organization, 33(2), 167-184.

Weisbenner, Z. I. S. (2008). Individual investor mutual fund flows. National Bureau of Economic Research, 53(9), 1689-1699.

Wilson, J. W., \& Jones, C. P. (2002). An analysis of the S \& P 500 index and Cowles's extensions: Price indexes and stock returns, 1870_1999. The Journal of Business, 75(3), 505-533. 
This page is intentionally left blank 